\title{
The role of fertiliser in the invasion of South Island high country by hawkweeds
}

\author{
WARWICK HARRIS' and JIANGWEN FAN ${ }^{2}$ \\ 'Manaaki Whenua-Landcare Research, PO Box 69, Lincoln \\ ${ }^{2}$ Commission for Integrated Survey of Natural Resources, Chinese Academy of Sciences, PO Box 767, Beijing,
}

100101, People's Republic of China

\section{Abstract}

An hypothesis, that the invasion of hawkweeds (Hieracium species) into South Island high country was triggered by fertiliser application from about 1950 , is examined. Reference is made to the historical occurrence of hawkweeds in New Zealand, volumes and patterns of fertiliser application to high country, and experimental and observational information about the response of hawkweeds to soil fertility. Both mouse ear (H. pilosella) and king devil (H. praealtum) hawkweeds show marked and rapid increases in vegetative growth and flowering when available soil nutrients are increased. The response of hawkweeds to soil fertility is much greater than that of fescue tussock (Festuca novae-zelandiae) but appears similar to that of most introduced grasses, legumes and weeds. A specific $P$ effect is inferred to explain why sheep's sorrel (Rumex acetosella) became an important weed of tussock grasslands before hawkweeds.

K eywords: fescue tussock, hawkweeds, Hieracium, high country, sheep's sorrel, soil fertility,

\section{Background -}

This paper examines the hypothesis that the invasion of high country pastoral lands by hawkweeds (Hieracium spp.) was triggered by the widespread application of phosphate-based fertilisers to these lands that has occurred since the 1950s.

Roseef $a /$. (1995) warn against acceptance of singlefactor explanations in seeking solutions to the hawk weed problem. They draw the contrast between hypotheses that explain hawkweed invasion as symptomatic of changes to tussock grassland environments (Treskonova 1991a.b) and those that see hawkweeds as aggressive invaders that degrade these environments (Scott 1984). The hypothesis examined here implicates phosphatic fertiliser as causing environmental changes that provided niches in which hawkweeds expressed their aggressive invader characteristics.

Various opinions have been expressed as to the nature of the environmental changes that allowed the invasion of high country by hawkweeds. Most emphasis has been given to the idea that it represents a stage in the progressive reduction of tussock cover brought about by fire, rabbits and overgrazing by stock (Hunter et al. 1992; Treskonova 1991a,b). Hunter et a/. (1992) concluded that while declines in soil fertility and soil organic matter had been implicated in the increase of hawkweeds, there was insufficient evidence to support this idea.

The first record of mouse-ear hawkweed $(H$. pilosella) in New Zealand is dated 1878 (GarnockJones 1987). Herbarium records show this species was regularly found after that date. It was noted as a potential weed in the Ashburton area in the 1920s (Allan 1924), but it was not until the 1970s that it became a major high country weed (Scott 1984). Scott considered that the extensive spread of hawkweeds began in the 1950s. Studies of the floristic composition of tussock grasslands in Canterbury show that by the early 1960s hawkweeds were well established in many of these grasslands, and particularly fescue tussock (Festuca novae-zelandiae) grasslands, and that they showed large increases in their presence in these grasslands between 1960 and 1990 (Connor 1992a,b; Treskonova 1991a).

Supporting the idea that reduced levels of soil fertility encouraged hawkweeds.are.demonstrations-that applications of $\mathrm{P}$ and $\mathrm{S}$ fertiliser together with sowing of legumes and grasses can markedly reduce its content in high country grassland (Espie 1994; Scott 1993; Scott et al. 1990). This is the classic method of pasture development and improvement in New Zealand whereby the mineral nutrient requirements of legumes for growth and fixation of $\mathrm{N}$ is met and fixed $\mathrm{N}$ is transferred to support growth of the grass component of the pasture. This method has underlain attempts to sustain and develop the pastoral resource of high country grasslands.

The hypothesis-presented-in-this paperarose iiipart from findings of an investigation of the effects of soil fertility level and herbage removal frequency on interference between mouse-ear hawkweed, king devil hawkweed $(H$. praealtum), sheep's sorrel (Rumex acetosella) and fescue tussock (Fan \& Harris 1996). This investigation examined the direct responses of these species to these effects when grown in monoculture and how these responses were modified by interference between the species grown in mixtures. Marked and 
rapid increase of vegetative growth (Figure 1) and flowering (Figure 2) of the hawkweeds in response to increased mineral nutrients contradicted the notion that these species were symptomatic of areas of depleted soil fertility.

Figure 1 Total growing season yields of monocultures of mouseear and king devil hawkweeds and fescue tussock in response to a soil fertility gradient. The gradient was established by incorporating fractional proportions of the slow-releasecompound fertiliser Plantacote $8 \mathrm{M}$ in the sand-clay mix used in a box experiment (Fan \& Harris 1996).

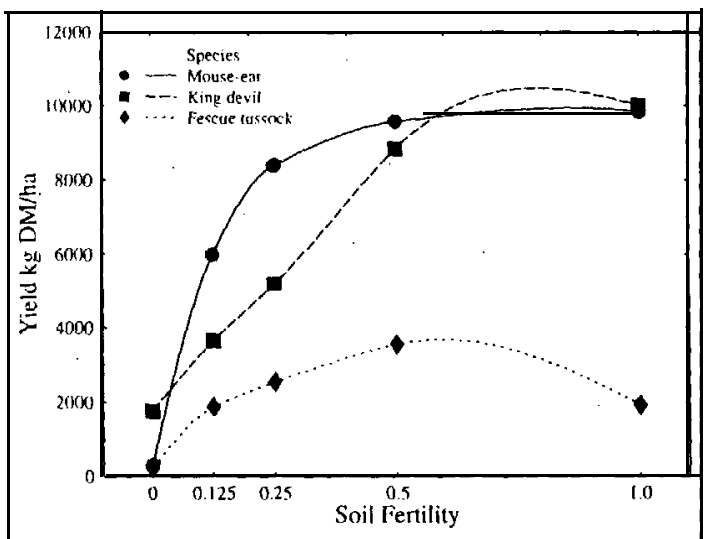

Figure 2 Flowering responses of mouse-ear and king devil hawkweeds and fescue tussock 6 weeks after planting in a soil fertility gradient. Details of the gradient are given with Figure 1.

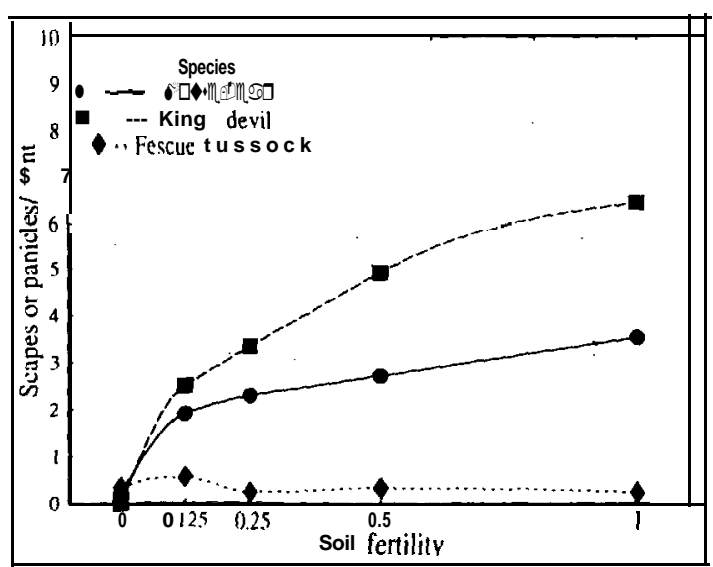

Another consideration involved seeking an answer as to why hawkweeds had not entered tussock grasslands sooner. Alteration of tussock cover by fire, rabbits and overgrazing had been under way for a hundred years before hawkweeds showed their massive invasion. Hawkweeds had been in New Zealand almost a century before this invasion. Had there been a change in management of tussock grasslands that triggered the invasion? One obvious change was aerial topdressing of high country to provide $\mathrm{P}$ and other nutrient requirements for legume growth.

\section{$\mathrm{H}$ istory of fertiliser application to high country}

Aerial topdressing began in 1949. Before that very little fertiliser had been applied to high country. From 1952 to 1962 fertiliser application to South Island high country more than doubled (Ward 1965). Between 1965 and 1973 there was a 4-fold increase in the area of tussock grassland fertilised and a doubling of the amount of fertiliser applied associated with a $25 \%$ increase of stock units (Hughes 1974). Kerr \& Lefevre (1984) recorded that between 1966 and 1982 stock units increased from 1.6 to 2.6 million. This was associated with an increase of fertiliser application per stock unit from $14.8 \mathrm{~kg}$ in 1972 to $21.3 \mathrm{~kg}$ in 1982 . After 1982 there was a smaller increase of stock units to reach 2.8 million in 1988, but during this time fertiliser application per run declined from 170 to 73 tonnes per run (Kerr \& Abrahamson 1988).

Within the long trends of fertiliser use there were marked annual fluctuations of application (Figure 3). As well, between runs (Kerr \& Lefevre 1984), and within runs, there was marked variation in the frequency and rate of application of fertiliser. Clearly there have been pulses of input of mineral nutrients into high country in recent decades. It is suggested that for large areas of high country the rate and regularity of fertiliser application has been insufficient to sustain the requirements of the forage grasses and legumes sown with these applications. Transfer of nutrients by livestock and by wind to parts of high country that have not been directly fertilised should also be considered. The P status of large areas of high country has been raised, but because of inadequate survival, growth and $\mathrm{N}$-fixation by sown legumes, the elevation of $\mathrm{N}$ levels has been insufficient to sustain sown forage grasses.

\section{Soil fertility responses}

The soil fertility gradient (Figures 1, 2, 4, 5) used by Fan \& Harris (1996) involved a compound fertiliser. This hastened the process whereby $\mathrm{P}, \mathrm{S}$ and other elements required for legume growth are elevated before $\mathrm{N}$ levels are raised by legume $\mathrm{N}$-fixation.

Grown in monoculture, both mouse-ear and king devil hawkweeds showed marked yield increases in 
Figure 3 Mean annual fertiliser use of about 30 South Island high country runs from 1969 to 1991. Data are from the New Zealand Meat and Wool Boards' Economic Service.

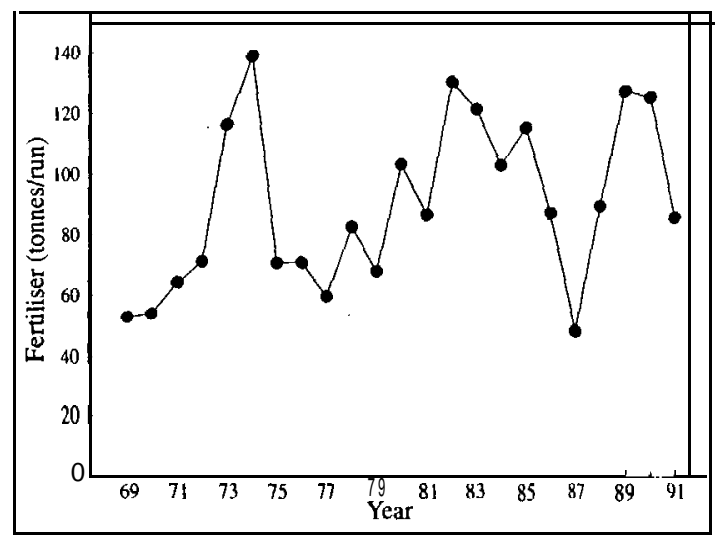

response to soil fertility (Figure 1). Fescue tussock showed a much smaller response, and, like other lowfertility grasses (Bradshaw et al. 1964), had reduced yield at the high soil fertility. As well as triggering vegetative growth to provide yield, increased fertility triggered flowering of the hawkweeds but not fescue tussock (Figure 2).

When grown in mixture with fescue tussock, increased soil fertility enabled mouse-ear hawkweed to rapidly fill the gaps between the tussocks and to give a marked yield response (Figure 4). This response also reduced the yield of the tussock plants compared with their growth in monoculture (Figure $1, \overline{4})^{-}$. In mark=contrast, when grown with sheep's sorrel, mouse-ear hawkweed yield was markedly suppressed when soil fertility was raised. Sheep's sorrel elevated its leaf canopy above that of the prostrate rosettes of mouse-ear hawkweed and virtually eliminated it by shading. In this way sheep's sorrel affected mouse-ear hawkweed in a way similar to that exerted by well established, adequately fertilised grass-legume pasture.

Fan \& Harris (1996) also measured residual biomass - \&the end of the growing season. This is the biomass that would initiate a new annual cycle of growth. Sheep's sorrel had almost eliminated mouse-ear hawkweed from the mixtures in which they occurred together (Figure 5). However, while its yield had been reduced by the presence of mouse-ear hawkweed, the residual biomass of fescue tussock was little affected. This points to the invasive strategy of mouse-ear hawkweed as being that of a filler of the gaps in open tussock stands. Weakening of tussocks by direct competitive effects exerted by mouse-ear hawkweed is less important.
Figure 4 Total growing season yields of the component species in mixtures of mouse-ear hawkweed and fescue tussock and mouse-ear hawkweed and sheep's sorrel in response to a fertility gradient. Details of the gradient are given with Figure 1.

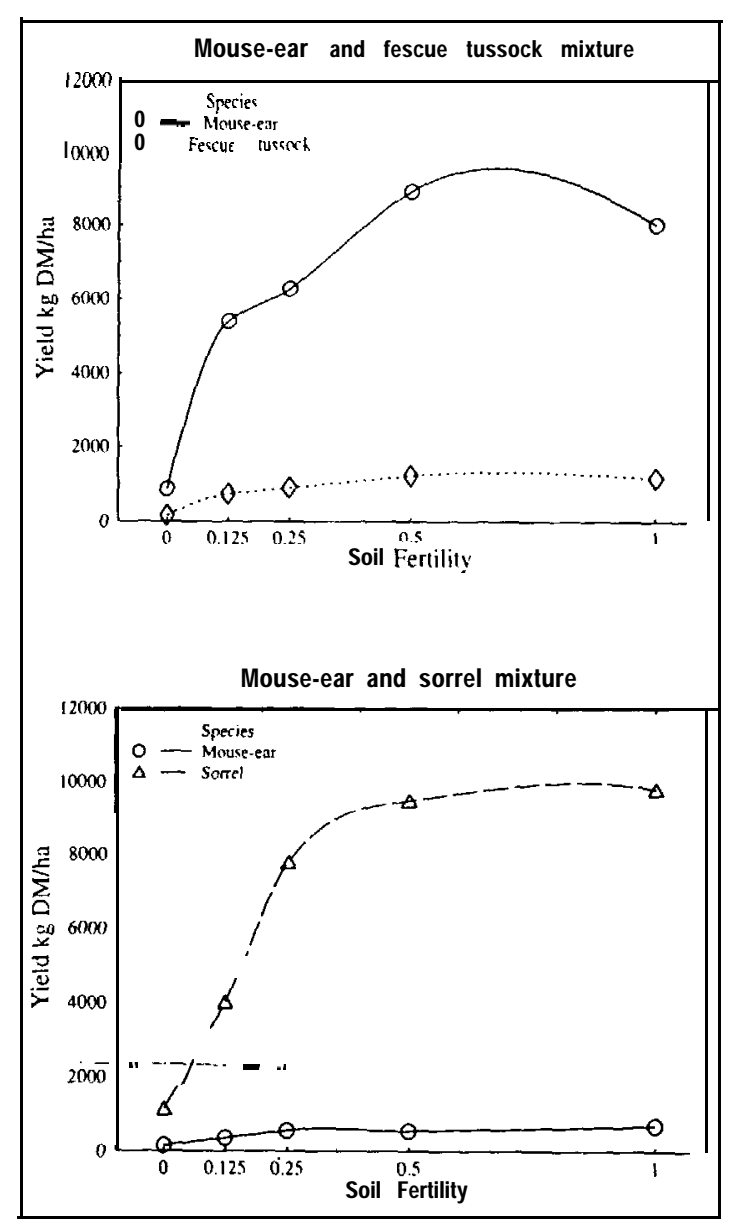

\section{The shift from sheep's sorrel to hawkweed}

Before 1960 the herbaceous weed of concern in high country was sheep's sorrel, not hawkweeds. It is suggested that the shift in their status as high-country weeds relates to their differentabilities-to-take-up-P.-

It is proposed that sheep's sorrel can obtain sufficient $P$ from that available in unfertilised high country soils. This ability may be linked to the species' capacity to elevate $\mathrm{pH}$ in its root zone (Harris 1971, 1972). The change of sheep's sorrel from the depauperate state in which it is usually seen in tussock grasslands to that where it blooms to redden the landscape (Moore 1954) is likely to be caused by $\mathrm{N}$ released by perturbations to nutrient pools induced by fire, rabbit activity and cultivation. 
Figure 5 Residual biomass left after completion of yield harvesting for the growing season of the component species in mixtures of mouse-ear hawkweed and fescue tussock and mouse-ear hawkweed and sheep's sorrel in response to a fertility gradient. Details of the gradient are given with Figure 1.

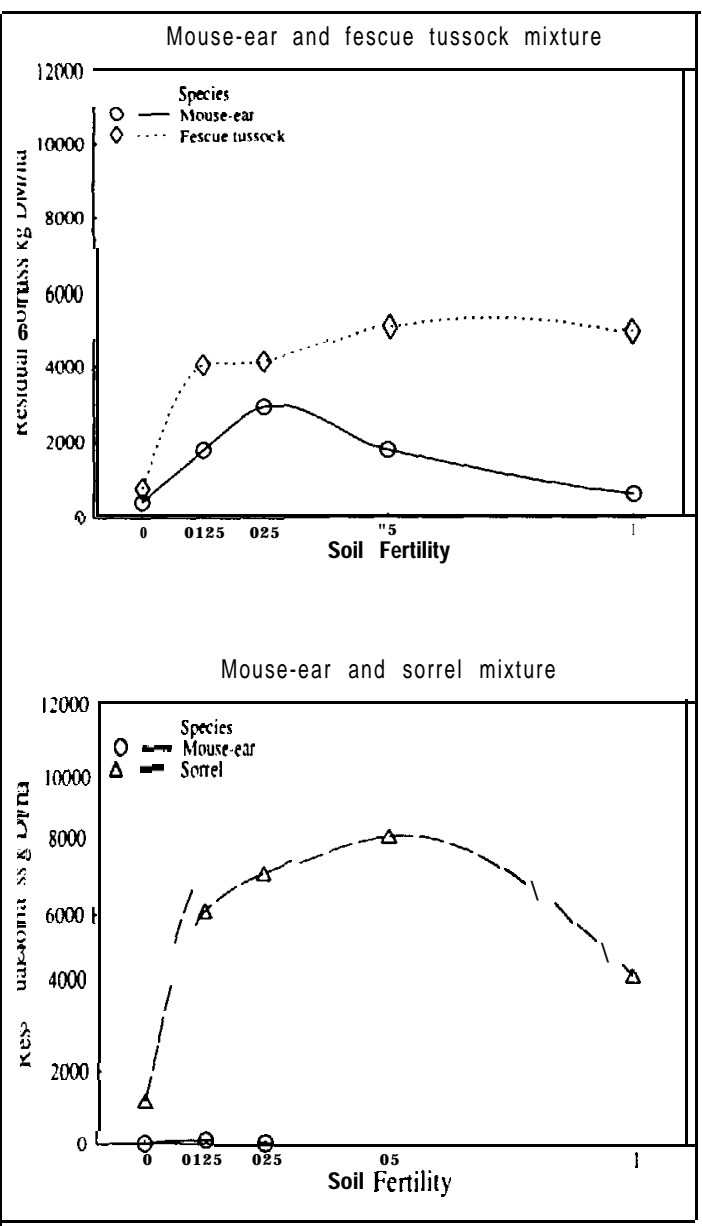

Hawkweeds. while present in tussock grasslands, remained latent until $P$ was made available by fertiliser application. In this respect they were similar to forage legumes. However, they may differ in the threshold levels of mineral nutrients required for survival and growth, and hawkweeds do not fix nitrogen. Failure of sown legumes to survive in the spaces between tussocks where $\mathrm{P}$ had been elevated created a widespread ecological niche in tussock grasslands that had not been present before the advent of aerial topdressing in 1949.

\section{Conclusion}

It is not claimed that the hypothesis is proven, It will be disputed, as some will see it as contrary to the agricultural development control strategy (Espie 1994). Nevertheless the information presented does point to the need for more detailed studies of the specific and threshold effects of $\mathrm{P}$ and other elements on the growth and competitive ability of hawkweeds and tussock grassland plants. Specific $P$ responses of hawkweeds have been indicated (Makepeace 1985; Svavarsdottir 1995). Information from experiments where specific factors are controlled, and their effects recorded, will complement information that has been obtained from field survey and monitoring and agronomic studies. There are serious dangers in applying control procedures that reduce the cover of hawkweeds if it is uncertain that there are other plants that can hold the ground they now occupy.

\section{ACKNOWLEDGEMENTS}

This contribution was made possible by grants from the Chinese Academy of Sciences, People's Republic of China, the Chinese Exchange Programme of the New Zealand Ministry of Foreign Affairs and Trade, and the New Zealand Foundation for Research Science and Technology.

\section{REFERENCES}

Allan, H.H. 1924. Notes on the occurrence of certain exotic plants in New Zealand. NZ journal of agriculture 29(5): 31 I-314.

Bradshaw, A.D.; Chadwick, M.J.; Jowett, D.; Snaydon, R.W. 1964. Experimental investigations into the mineral nutrition of several grass species IV. Nitrogen levels. Journal of ecology 52: 665-676.

Connor, H.E. 1992a. Hawkweeds, Hieracium spp., in tussock grasslands of Canterbury, New Zealand, in 1960s. NZ journal of botany 30: 247-261,

Connor, H.E. 1992b. The botany of change in tussock grasslands in the Mackenzie country, south Canterbury, New Zealand. Review. Journal of the New Zealand Mountain Lands Institute 49: 1-31.

Espie, P.R. 1994. Integrated pastoral management strategies for Hieracium control. Proceedings of the New Zealand Grassland Association 56: 243247.

Fan, Jiangwen; Harris, W. 1996. Effects of soil fertility level and cutting frequency on interference among Hieracium pilosella, H. praealtum, Rumex acetosella, and Festuca novae-zelandiae. NZjournal of agricultural research 39: I-32. 
Garnock-Jones, P.J. 1987. Checklist of dicotyledons naturalised in New Zealand 19. Asteraceae (Compositae) subfamily Cichorioideae. NZ journal of botany 25: 503-510.

Harris, W. 1971. The effects of fertiliser and lime on the competitive interactions of Rumex acetosella L. with Trifolium repens L. and Lolium sp. NZ journal of agricultural research 14: 185-207.

Harris, W. 1972. Shading, defoliation, temperature, growth stage and residual fertility effects on competition between Rumex acetosella, Trifolium repens and Lolium (multiflorum $\times$ perenne). NZ journal of agricultural research 15: 687-705.

Hughes, J.G. 1974. Changes in high country pastoral production in recent years. Review. Journal of the Tussock Grasslands and Mountain Lands Institute 29: 64-86.

Hunter, G.G.; Mason, CR.; Robertson, D.M. 1992. Vegetation changes in tussock grasslands, with emphasis on hawkweeds. New Zealand Ecological Society occasional publication no. 2.

Kerr, I.G.C.; Abrahamson, M. 1988. Trends in high country farming $1981 / 82$ to 1986/87. Review. Journal of the Tussock Grasslands and Mountain Lands Institute 45: 31-34.

Kerr, I.G.C.; Lefevre, K.R. 1984. High country farming 1966-1982. Review. Journal of the Tussock Grasslands and Mountain Lands Institute 42: 5882 .

Makepeace, W. 1985. Some establishment characteristics of mouse-ear and king devil hawkweeds. NZ journal of botany 23: 91-100.
Moore, L.B. 1954. Some Rumex acetosella communities in New Zealand. Vegetatio 5-6: 268-278.

Rose, A.B.; Platt, K.H.; Frampton, C.M. 1995. Vegetation change over 25 years in a New Zealand short-tussock grassland: effects of sheep grazing and exotic invasions. NZ journal of ecology 19(2): 163-174.

Scott, D. 1984. Hawkweeds in run country. Review. Journal of the Tussock Grasslands and Mountain Lands Institute 42: 33-48.

Scott, D. 1993. Response of Hieracium in two long term manipulative agricultural trials. $N Z$ journal of ecology 17: 41-51.

Scott, D.; Robertson, J.S.; Archie, W.J. 1990. Plant dynamics of New Zealand tussock grasslands infested with Hieracium pilosella 1. Effects of seasonal grazing, fertiliser and overdrilling. Journal of applied ecology 27: 224-243.

Svavarsdottir, K. 1995. Effects of added nutrients on species composition in native tussock grasslands of New Zealand. PhD thesis. Lincoln University.

Treskonova, M. 1991a. Changes in the structure of tall tussock grasslands and infestation by species of Hieracium in the Mackenzie Country, New Zealand. NZ journal of ecology 15(1): 65-78.

Treskonova, M, 1991b. Hieracium - an ecological perspective. Review. Journal of the New Zealand Mountain Lands Institute 48: 32-40.

Ward, F.L. 1965. High country farming in the South Island of New Zealand. New Zealand Meat and Wool Boards 'Economic Service bulletin 13: 1-I 3. 